\title{
Work stress and work based learning in secondary education: Testing the Karasek model
}

\author{
Kitty Kwakman
}

University of Twente, Netherlands

\begin{abstract}
Paper presented at the European Conference on Educational Research, Lahti, Finland 22-25 September 1999
\end{abstract}

\begin{abstract}
In this study the Job Demand-Control model was used to study the quality of working life of Dutch secondary teachers. The Job Demand-Control model of Karasek is a theoretical model in which stress and learning are both considered as dependent variables which are influenced by three different task characteristics: job demands, job control, and social support. This model was tested for Dutch secondary teachers $(n=542)$. Results shed light on the relationships between task characteristics, work stress, and work based learning. However, it is concluded that the Karasek model is better suited for explaining stress than for explaining learning. To explain work based learning more factors have to be taken into account in order to built an adequate theoretical model.
\end{abstract}

\section{Introduction}

The Job Demand-Control model of Karasek is originally a model of work stress (Karasek \& Theorell, 1990). The model proposes that work stress results from the joint effects of the demands of a work situation (job demands) and the discretion permitted to the worker in how to meet these demands: job control. Control refers to the opportunity to act autonomously and independently within the job and to exercise influence over decisions regarding working conditions and organisational issues. The major prediction of the model is that stress will occur when job demands are high and control is low, whereas the second prediction is that learning and grow will occur in situations where both job demands and control are high. Actually, the model is based on the interaction between two social-psychological factors. On the one hand the assumption is that control is needed to fulfil high job demands, on the other hand it is assumed that high job demands are a prerequisite for work based learning. However, to prevent work stress from high job demands, control is considered a crucial factor.

From the model two different hypotheses can be deduced: the strain hypothesis and the learning hypothesis. The first hypothesis is that work stress will occur when job 
demands are high whereas control is low. The second hypothesis is that learning and grow will occur in situations where both job demands and control are high.

The strength of this model is that it relates stress to learning, whereas both dependent variables are determined and explained by the same task characteristics. Therefore, the Karasek model offers an interesting perspective for research into the quality of teachers' working lives and for research into teacher development as well. Several authors have introduced the model as a promising approach to investigate the quality of working life in schools in the Netherlands (Christis, 1992; De Jonge, 1992; Van der Krogt, 1995; Onstenk, 1997).

But, researchers also criticise the model. First, it is remarked that most studies only investigated the stress hypothesis, whereas the learning hypothesis is hardly tested. Second, results give rise to question the validity of the model (De Jonge, 1992). The way the main variables have to be defined and operationalised remains unclear whereas empirical evidence confirming interaction effects is scarce. Moreover, the amount of explained variance of main effects is rather low in all studies. Although different arguments are given for these disappointing results, it is often stated that the model is too simple and that it lacks a very important variable in explaining stress and work based learning that has to be added to the model: social support.

In this research, which is originally a study into teacher learning at the workplace, the Karasek model was considered an interesting theoretical framework to explain teacher learning during the career. As a result of recent educational innovations, which aim at improving the quality of education, the quality of teachers' working lives has become a popular theme, especially in secondary education.

Consequently, it is more and more stressed that teacher development is a vital condition in educational improvement. There is a urgent need for researchers as well as for practitioners to gain more insight into factors that enhance or inhibit hinder teacher learning and development, especially in the workplace (Kwakman, 1998).

Therefore, research was started to test the assumptions of the Karasek model for teachers in secondary education. In testing the model the criticism based on current research findings was taken into account. So, 1) the model was tested for the stress hypothesis as well as for the learning hypothesis, 2) only main effects were investigated, and 3) the task characteristic 'social support' was added as a third independent variable.

Eventually, three research questions were addressed:

What empirical evidence is there for hypotheses derived from the Karasek model for teachers in secondary education?

What are the main effects of demands, control, and social support on work stress? 
What are the main effects of demands, control, and social support on work based learning?

\section{Method}

\section{Procedure}

Data used were collected in a research about teacher learning at the workplace (Kwakman, 1999). Data collection took place in the spring of 1997 by means of a survey. From all 939 teachers working in ten schools for secondary education 542 teachers returned a questionnaire (response rate of 59\%). The sample was not randomly selected as schools were participating that were interested in the research topic and results.

\section{Respondents}

The sample of 542 teachers consists of 367 men (68,3\%) and 170 women (31,7\%). The majority of these teachers is in the category of $40-60$ years $(73,9 \%)$ which indicates that in this respect the sample is slightly older and therefore not fully representative for the total population of teachers in the Netherlands. The mean age of the sample is 45,8 years $(\mathrm{sd}=9.0)$ whereas their mean working experience is 20,1 years $(\mathrm{sd}=9.8)$.

Considering the subject matter in which teachers teach the most, the group is divided as follows: 174 teachers teach languages (33\%); 99 teachers are teaching sciences (18,8\%); 79 teachers teach social sciences (15\%); 76 teachers are teaching arts or physical education (14,4\%); 60 of them are involved in vocational education $(11,1 \%)$; and 40 teachers are teaching national curriculum subjects $(7,6 \%)$.

\section{Variables}

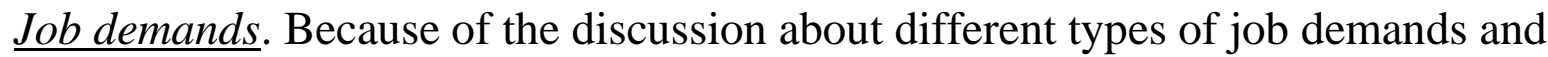
the questions raised in reviews of the Karasek model, three types of job demands were included in this research. First, pressure of work referring to quantitative demanding aspects such as the pace of work and workload. Second, emotional demands as referring to the extent in which the job requires emotional investment. Third, job variety measuring the availability of learning opportunities as well as the amount of diversity the work offers. All three variables were operationalised by means of twenty items derived from a questionnaire of the Dutch Institute of Working Conditions (VBBA; Van Veldhoven \& Meijman, 1994). Teachers were asked to indicate to what extent each item was relevant to their job on a 4-point scale (rating from 1 'hardly ever' to 4 'always').

Job control. A lot of discussion is going on in the literature about the meaning of the control variable in the Karasek model (Ganster, 1989). In this research, two 
different aspects of control were included: autonomy and participation. Autonomy refers to the opportunity of the worker to determine different task characteristics such as the pace of work, the method, and work order (De Jonge et al., 1994). Participation refers to the influence a worker has over the working environment and the opportunity to take part in decision making (Christis, 1992). Both variables were measured with fourteen items derived from the VBBA.

Social support. Support refers to the total amount of helpful social interaction of colleagues and staff that is available within the work context (Karasek \& Theorell, 1990). Especially instrumental and social-emotional aspects are of importance. Management support and collegial support were measured each by four 4-point items derived from a Dutch questionnaire on organisational stress (VOS-D; Bergers et al., 1986).

Work stress. This was measured by means of seven items derived from the Dutch

Version of the Maslach Burnout Inventory for Teachers (Schaufeli, Daamen \& Van Mierlo, 1994). Burnout is a metaphor for mental strain, which exists of three different components: emotional exhaustion, depersonalisation, and negative feelings about one's competence. In accordance with research findings and reliability of scales, items were selected only from the scales emotional exhaustion and loss of personal accomplishment. Emotional exhaustion refers to the extent in which teachers feel emotionally over-extended whereas loss of personal accomplishment refers to a decline of feelings of competence and successful achievement in one's job. All seven items are scored on a 7-point scale: $0=$ never, $1=$ hardly ever, 2 = seldom, $3=$ sometimes, $4=$ often, $5=$ nearly always, $6=$ always.

Work based learning. This variable was measured as performance of professional activities; activities help teachers develop professionally. These can be executed individually aimed at keeping up, experimenting, or reflecting but these activities can also be executed collaboratively, aimed at cooperation in policy and practical matters. Eventually, this variable was measured by twenty-one items. Teachers were asked to state how often they performed each professional activity on a 4point scale $(1=$ hardly ever, 2 = sometimes, $3=$ fairly often, $4=$ often $)$.

\section{Analysis}

First, factorial analyses were used to construct scales (Principal Component Analysis). For answering the first research question hypotheses derived from the Karasek model were tested. Therefore, two groups with different combinations of scores on job demands and job control were compared and differences between groups were tested (t-tests). For an answer to the second and third question, regression analysis was executed to determine effects of different task characteristics on stress and learning. 


\section{Results}

\section{Scales}

Professional activities. Results of factorial analyses are only presented for the key dependent variable measuring work based learning. Principal Component Analysis (oblique rotation) yielded three different factors (40,5\% explained variance). Three items had to be removed. Table 1 shows the factor loadings of different items.

Table 1. Factor loadings of items representing professional activities

\begin{tabular}{|c|c|c|c|}
\hline & $\begin{array}{r}\text { Factor } \\
1\end{array}$ & $\begin{array}{r}\text { Factor } \\
2\end{array}$ & $\begin{array}{r}\text { Factor } \\
3\end{array}$ \\
\hline$\underline{\text { Task extension }}$ & & -.06 & -.09 \\
\hline Give opinion to school management & .80 & 05 & -07 \\
\hline Participate in pupil counselling policy & .73 & 01 & -01 \\
\hline Join a committee at the school & .68 & 12 & 11 \\
\hline Discuss about educational improvement & .62 & 07 & .23 \\
\hline $\begin{array}{l}\text { Share ideas about education with colleagues } \\
\text { Support colleagues in teaching problems }\end{array}$ & .56 & .07 & .14 \\
\hline$\underline{\text { Professional improvement }}$ & -.14 & .66 & .15 \\
\hline Study subject matter literature & .08 & .60 & .00 \\
\hline $\begin{array}{l}\text { Read professional journals } \\
\text { Ask pupils feedback }\end{array}$ & .11 & .60 & -.17 \\
\hline Experiment with new teaching methods & -.11 & .51 & .07 \\
\hline & .17 & .46 & -.18 \\
\hline $\begin{array}{l}\text { Adapt way of teaching to pupils needs } \\
\text { Teach students study skills }\end{array}$ & .15 & .45 & .11 \\
\hline Instructional practice & & & \\
\hline Prepare lessons with colleagues & .10 & -.13 & .71 \\
\hline Construct teaching materials & -.14 & .12 & .65 \\
\hline Discuss way of teaching with colleagues & .10 & .04 & .50 \\
\hline
\end{tabular}


The first factor consists of six professional activities that are all executed collaboratively and are related to extracurricular and organisational tasks. So, this factor was called task extension. The second factor includes seven items referring to activities that are performed individually or in interaction with pupils. As all these activities are mainly aimed at keeping up with new information and improving lessons this factor was named professional improvement. The third factor comprises of five professional activities which all are referring to practical instructional work related to preparing and giving lessons. Therefore, this factor was labelled instructional practice (Kwakman, 1999).

\section{Other variables}

Concerning all other variables in this study, factorial analyses gave rise to construct nine scales in accordance with the assumed multidimensionality of the variables measured. Descriptive statistics (also of the three types of professional activities) are presented in Table 2, whereas correlations between dependent and independent variables are shown in Table 3. The mean scores in Table 2 all point to the same direction: the higher the score, the more this characteristic was perceived to be present in the work situation.

Table 2. Descriptive statistics of scales

\begin{tabular}{|c|c|c|c|c|c|}
\hline & $M$ & Range & $S D$ & Alpha & $\begin{array}{l}\text { Number } \\
\text { of items }\end{array}$ \\
\hline Pressure of work & 2.41 & $1-4$ & .56 & .87 & 7 \\
\hline Emotional demands & 2.12 & $1-4$ & .49 & .64 & 3 \\
\hline Job variety & 2.66 & $1-4$ & .52 & .82 & 7 \\
\hline Autonomy & 2.65 & $1-4$ & .54 & .73 & 5 \\
\hline Participation & 2.38 & $1-4$ & .55 & .76 & 5 \\
\hline Management support & 2.95 & $1-4$ & 69 & .87 & 5 \\
\hline Collegial support & 3.21 & $1-4$ & .55 & .79 & 4 \\
\hline Emotional exhaustion & 2.68 & $0-6$ & 1.08 & .82 & 3 \\
\hline Loss of personal accomplishment & 2.20 & $0-6$ & .68 & .72 & 4 \\
\hline
\end{tabular}




\begin{tabular}{|l|r|r|r|r|r|}
\hline Task extension & 2.29 & $1-4$ & .58 & .77 & 6 \\
\hline Professional improvement & 2.43 & $1-4$ & .46 & .65 & 7 \\
\hline Instructional practice & 2.25 & $1-4$ & .49 & .58 & 5 \\
\hline
\end{tabular}

Table 3. Correlations between independent and dependent variables

\begin{tabular}{|l|l|l|l|l|l|}
\hline & $\begin{array}{l}\text { Emotional } \\
\text { Exhaustion }\end{array}$ & $\begin{array}{l}\text { Loss of ac- } \\
\text { complishment }\end{array}$ & $\begin{array}{l}\text { Task } \\
\text { extension }\end{array}$ & $\begin{array}{l}\text { Professional } \\
\text { improvement }\end{array}$ & $\begin{array}{l}\text { Instructional } \\
\text { practice }\end{array}$ \\
\hline Pressure of work & $.56^{*}$ & $.13^{*}$ & $.15^{*}$ & .02 & .05 \\
\hline Emot. demands & $.40^{*}$ & $.14^{*}$ & $.20^{*}$ & $.16^{*}$ & $.15^{*}$ \\
\hline Job variety & $-.32 *$ & $-.40^{*}$ & $.26^{*}$ & $.26^{*}$ & $.17^{*}$ \\
\hline Autonomy & $-.29^{*}$ & $-.28^{*}$ & .08 & .08 & .04 \\
\hline Participation & $-.23^{*}$ & $-.33^{*}$ & $.27^{*}$ & $.12^{*}$ & $.11^{*}$ \\
\hline Management support & $-.24^{*}$ & $-.28^{*}$ & $.11^{*}$ & .02 & $.09 *$ \\
\hline Collegial support & $-.27^{*}$ & $-.29 *$ & $.12^{*}$ & .05 & $.21^{*}$ \\
\hline
\end{tabular}

* significant correlation $(\mathrm{p}<.05$, two-tailed $)$

\section{First research question}

To answer the question "What empirical evidence is there for hypotheses derived from the Karasek model for teachers in secondary education?" two hypotheses were tested:

Teachers who perceive their job as high in job demands but low in job control will report more stress than teachers who perceive their job as high in job demands but high in job control.

Teachers who perceive their job as high in job demands but high in job control will perform professional activities more frequently than teachers who perceive their job as high in job demands but low in job control.

To test these hypotheses teachers were first divided into two groups based on both scores on job control. Teachers with a score of (more than) one standard deviation above the mean on both control variables were considered as having high job control $(\mathrm{n}=161)$ and teachers with a score of (more than) one standard deviation below the mean as having low job control $(n=149)$. Next, teachers were further selected based on their scores on job demands following the same procedure for each job demands separately. Thus, only teachers with high job demands were 
included in the analyses. Eventually, differences between two groups (high job demands with low control versus high job demands with high job control) on stress and professional activities were compared for each type of job demand. When groups differed significantly, the effect was expressed in a measure $d$ (raw difference between means divided by the standard deviation of the total group). For results, see Table 4 .

Table 4. Mean scores on stress en professional activities for groups with different combinations of job demands and control, results of t-test, and effects

\begin{tabular}{|c|c|c|c|c|c|}
\hline \multirow[b]{2}{*}{$\begin{array}{l}\text { Combination of } \\
\text { job demands x control }\end{array}$} & \multicolumn{2}{|l|}{ Stress } & \multicolumn{3}{|c|}{ Professional activities } \\
\hline & $\begin{array}{l}\text { Emotional } \\
\text { exhaustion }\end{array}$ & $\begin{array}{l}\text { Loss of } \\
\text { accomp- } \\
\text { lishment }\end{array}$ & $\begin{array}{l}\text { Task } \\
\text { extension }\end{array}$ & $\begin{array}{l}\text { Prof. } \\
\text { improve- } \\
\text { ment }\end{array}$ & $\begin{array}{l}\text { Instructio- } \\
\text { nal practice }\end{array}$ \\
\hline High pressure $\mathrm{x}$ low control $(\mathrm{n}=15)$ & 3.70 & 2.59 & 2.31 & 2.52 & 2.29 \\
\hline \multirow[t]{2}{*}{ High pressure $x$ high control $(n=50)$} & 3.16 & 1.98 & 2.61 & 2.61 & 2.27 \\
\hline & $\begin{array}{l}\mathrm{p}=.03 \\
d=.50\end{array}$ & $\begin{array}{l}\mathrm{p}=.00 \\
d=.90\end{array}$ & $\begin{array}{l}\mathrm{p}=.05 \\
d=.52\end{array}$ & n.s. & n.s. \\
\hline $\begin{array}{l}\text { High emot. demands } x \text { low control } \\
(\mathrm{n}=26)\end{array}$ & 3.68 & 2.47 & 2.35 & 2.49 & 2.23 \\
\hline \multirow[t]{2}{*}{$\begin{array}{l}\text { High emot. demands } x \text { high control } \\
(\mathrm{n}=41)\end{array}$} & 2.71 & 2.05 & 2.74 & 2.75 & 2.40 \\
\hline & $\begin{array}{l}\mathrm{p}=.00 \\
d=.90\end{array}$ & $\begin{aligned} \mathrm{p} & =.001 \\
d & =.62\end{aligned}$ & $\begin{array}{r}\mathrm{p}=.001 \\
d=.67\end{array}$ & $\begin{array}{r}\mathrm{p}=.035 \\
d=.57\end{array}$ & n.s. \\
\hline High job variety x low control (n=9) & 2.19 & 2.03 & 2.29 & 2.41 & 2.25 \\
\hline \multirow[t]{2}{*}{ High job variety $\mathrm{x}$ high control $(\mathrm{n}=42)$} & 2.19 & 1.75 & 2.62 & 2.63 & 2.20 \\
\hline & n.s. & n.s. & n.s. & n.s. & n.s. \\
\hline
\end{tabular}

With regard to the first hypothesis the conclusion is that this hypothesis is confirmed for two types of job demands: in case of high pressure and high emotional demands in combination with low job control, stress is significantly higher than in combination with high control. The measure $d$ indicates that the differences are quite large. With regard to job variety the hypothesis proved to be not valid. 
With regard to the second hypothesis the conclusion is drawn that it is only confirmed for pressure of work and for emotional demands. Only in case of high pressure combined with high control task extension activities are more frequently performed. In case of high emotional demands combined with high control, task extension activities as well as professional improvement activities are significantly more frequently executed than in combination with low control.

\section{Second and third research question}

The research questions into the main effects of demands, control, and social support on work stress and on work based learning were answered using multiple regression analyses. Results are presented in Table 5.

Table 5. Significant standardised beta coefficients of two stress variables and three types of professional activities $(\mathrm{p}<.05)$

\begin{tabular}{|c|c|c|c|c|c|}
\hline & $\begin{array}{l}\text { Emotional } \\
\text { exhaustion }\end{array}$ & $\begin{array}{l}\text { Loss of accomp- } \\
\quad \text { lishment }\end{array}$ & $\begin{array}{c}\text { Task } \\
\text { extension }\end{array}$ & $\begin{array}{l}\text { Professional } \\
\text { improvement }\end{array}$ & $\begin{array}{c}\text { Instructional } \\
\text { practice }\end{array}$ \\
\hline Pressure of work & .43 & & .15 & & \\
\hline Emot. demands & .19 & .10 & .15 & .18 & .16 \\
\hline Job variety & -.23 & -.29 & .20 & .27 & .15 \\
\hline \multicolumn{6}{|l|}{ Autonomy } \\
\hline Participation & & -.13 & .26 & & \\
\hline \multicolumn{6}{|c|}{ Management support } \\
\hline Collegial support & -.11 & -.16 & & & .23 \\
\hline $\mathrm{R} ?$ & .41 & .24 & .17 & .10 & .10 \\
\hline
\end{tabular}

Noteworthy is first that the variables 'autonomy' and 'management support' show no direct effects on any of the dependent variables. Second, it may be remarked that in comparison with the correlation analysis (see Table 3), regression analysis in which joint effects are determined gives a better insight into variables that are most important.

Regarding the first stress variable 'emotional exhaustion', four variables show some significant direct effects whereas the amount of explained variance is reasonable high.

Regarding the direction of effects, higher pressure of work and higher emotional demands relate to more emotional exhaustion whereas higher job variety and collegial support relate to less exhaustion. Concerning the second stress variable, 
also four effects proved to be significant, but the amount of explained variance is much smaller. Higher emotional demands relate to more loss of accomplishment whereas job variety, participation, as well as collegial support relate to lower scores, so to less stress.

With regard to the three types of professional activities, the amounts of explained variances only point to some minor effects. All effects are positive. Whereas emotional demands and job variety effect all three types, pressure of work and participation only effects task extension activities, and collegial support effects instructional practice.

\section{Conclusions and discussion}

With regard to the first research question it is concluded that hypotheses from the model of work stress are partly confirmed. The results show that there is indeed some relationship between stress and learning which is mediated by the amount of job control. For teachers who perceive their job as having much pressure and high emotional demands a high level of job control goes along with a lower level of job stress and a higher frequency of some professional activities. On the contrary, teachers perceiving high job demands with low job control report a higher level of job stress and a lower frequency of some professional activities.

Results with regard to the second and third research question show that characteristics of the Karasek model of work stress explain a larger amount of the variance in stress than in professional activities. This means that the Karasek model is better suited for explaining stress than for explaining the performance of professional activities. The addition of social support as third independent variable appears to be worthwhile as it yielded some extra effects for stress as well as for learning. This only account for social support of colleagues as management support does not yielded any effect at all.

Although the main effects of the control variables are small, it may not be concluded that these variables are not important in explaining stress or work based learning. For the group of teachers that perceive their work as high in pressure and high in emotional demands, the amount of control does make a difference. The conclusion is that this group of teachers is a group that needs more attention and study. A first step would be to examine why these teachers perceive their task characteristics differently. In general, as this study shows that teachers' perceptions of their task characteristics differ to a very large extent, more research into the origins and influences of these perceptions is needed.

In sum, to explain work based learning we have to look further for more variables in order to built an adequate theoretical model. As this study shows, task characteristics only play a modest role in teacher learning in the workplace. 


\section{References}

Bergers, G.P.A. , Marcelissen, F.H.G. \& Wolff, CH. J. de (1986). VOS-D.

Vragenlijst Organisatiestress-D: handleiding. [VOS-D. Work stress questionnaire]. Nijmegen: University of Nijmegen.

Christis, J. (1992). Taakbelasting en taakverdeling. Een methode voor aanpak van werkdruk in het onderwijs. [Task demands and taskdivision. A method to reduce job stress in education]. Amsterdam: NIA.

Ganster, D.C. (1989). Worker control and well-being: A review of research in the workplace.

In: S.L. Sauter, J.J. Hurrell \& C.L. Cooper (Eds.), Job control and worker health (pp.

3-23). Chichester: Wiley \& Sons.

Jonge, J. de (1992). Autonomie in het werk: Een literatuuroverzicht. [Job autonomy: A review of the literature]. Maastricht: Rijksuniversiteit Limburg.

Jonge, J. de, Landeweerd, J.A. \& Breukelen, G.J.P. van (1994). De Maastrichtse autonomielijst: Achtergrond, constructie en validering. [The maastricht job autonomy questionnaire: background, construction, and validity]. Gedrag \& Organisatie, 7, 27-41.

Karasek, R. \& Theorell, R. (1990). Healthy work: Stress, productivity, and the reconstruction

of working life. New York: Basic Books.

Krogt, F.J. van der (1995). Leren in netwerken. Veelzijdig organiseren van leernetwerken met het ook op humaniteit en arbeidsrelevantie. [Learning in networks]. Utrecht: Lemma.

Kwakman, K. (1998). Professional learning on the job of Dutch secondary teachers: In search of relevant factors. Journal of In-service Education, 24, pp. 5771.

Kwakman, K. (1999). Leren van docenten tijdens de beroepsloopbaan. Studies naar professionaliteit op de werkplek in het voortgezet onderwijs. [Teacher learning throughout the career]. Proefschrift Katholieke Universiteit Nijmegen. 
Onstenk, J.H.A.M. (1997). Lerend leren werken. Brede vakbekwaamheid en de integratie van leren, werken en innoveren. [Learning to learn working]. Proefschrift Katholieke Universiteit Nijmegen. Delft: Eburon.

Schaufeli, W.B, Daamen, J. \& Mierlo, H. van (1994). Burnout among Dutch teachers: An

MBI-validity study. Educational and Psychological Measurement, 54, 803-812.

S derfeldt, B., S derfeldt, M., Muntaner, C., O’Campo, P., Warg, L.E. \& Ohlson, C.G.

(1996). Psychosocial work environment in human service organizations: A conceptual analysis and development of the demand-control model. Social Science \& Medicine, 42, 1217-1226.

Veldhoven, M. van \& Meijman, T. (1994). Het meten van pscychosociale arbeidsbelasting met een vragenlijst: De vragenlijst beleving en beoordeling van arbeid (VBBA). [Questionnaire social psychological work demands]. Amsterdam: NIA. 